\title{
Precolonial development of technology in tropical Africa : updating a review
}

Jouke S. Wigboldus

\section{(2) OpenEdition \\ 1 Journals}

Electronic version

URL: https://journals.openedition.org/tc/715

DOI: $10.4000 /$ tc. 715

ISSN: 1952-420X

Publisher

Éditions de l'EHESS

\section{Printed version}

Date of publication: 1 November 1992

ISSN: 0248-6016

\section{Electronic reference}

Jouke S. Wigboldus, "Precolonial development of technology in tropical Africa : updating a review",

Techniques \& Culture [Online], 17-18 | 1992, Online since 10 January 2006, connection on 29 September 2022. URL: http://journals.openedition.org/tc/715 ; DOI: https://doi.org/10.4000/tc.715

This text was automatically generated on 29 September 2022.

All rights reserved 


\section{Precolonial development of technology in tropical Africa : updating a review}

Jouke S. Wigboldus 